УДК 543.613.2+ 556.142+624.161.6

(C) 2014

Сененко Н. Б., кандидат фізико-математичних наук, Стороженко Д. О., кандидат хімічних наук

Полтавський національний технічний університет ім. Юрія Кондратюка

Сененко А. І., молодший науковий співробітник

Інститут фізики Національної академії наук України

\author{
Писаренко П. В., доктор сільськогосподарських наук, професор, \\ Степаненков Г. В., аспірант \\ (науковий керівник - доктор сільськогосподарських наук, професор П. В. Писаренко) \\ Полтавська державна аграрна академія
}

\title{
СПОСІБ ОЧИСТКИ ПИТНОЇ ВОДИ ВІД НІТРАТ-ІОНІВ
}

\section{Рецензент - доктор технічних наук В. О. Бондар}

Визначений хімічний склад проби глинистої сировини. Представлені результати експериментальних досліджень ї̈ сорбиійних характеристик у повітряно-сухому стані й термічно обробленої за різних режимів відносно нітрат-іонів. Досліджені основні фізико-хімічні показники якості природної питної води до та після обробки обраним сорбентом; визначені його десорбчійні характеристики. Виявлена можливість зменшення концентрації нітрат-іонів $у$ водi. Розроблені рекомендації з очищення природної питної води від нітрат-іонів.

Ключові слова: глиниста сировина, нітратіони, адсорбиія, водоносний горизонт, природна питна вода.

Постановка проблеми. Сучасний рівень техногенного навантаження на навколишнє середовище спричиняє забруднення грунту та його водорозчинної складової токсичними домішками. Наслідком цього забруднення є перевищення допустимих норм нітрат-іонів у водоносному горизонті, воду 3 якого населення використовує для питних цілей. Загальновідомий патогенний вплив нітрит- та нітрат-іонів на організм людини $[3,4]$. Солі нітратної кислоти (нітрати) - одні 3 найпоширеніших токсичних забруднювачів. Джерелами такого забруднення нітратні добрива, що інтенсивно і нераціонально використовуються в сільському господарстві, надлишок яких просто змивається дощовою водою 3 площини водозабору в поверхневі води або з часом просочується в грунтові води; продукти гниття органічних речовин, які можна було б використати для створення органічних добрив і подальшого їx використання; нафтогазовий комплекс, який у якості бурового розчину i реагентів-інтенсифікаторів використовує нітрати; промислові та комунально-побутові відходи і стоки та ін.
Проблема забруднення першого водоносного горизонту нітрат-іонами $€$ вкрай суттєвою для Полтавської області, в якій немає жодного району без перевищення цього показника у воді децентралізованого водопостачання $[4,15]$, чим i викликана актуальність нашого дослідження.

Аналіз останніх досліджень і публікацій, у яких започатковано розв'язання проблеми. Нітрати, як свідчать джерела, накопичуються у воді і продуктах харчування, після чого потрапляють в організм тварин і людей. Здатність нітратів відновлюватися в організмі людини до нітрит-іонів спричиняє утворення метгемоглобіну. За тривалого вжитку води із підвищеним вмістом нітрит- і нітрат-іонів спостерігаються розлади у роботі травної, серцево-судинної та нервової систем. Під впливом мікроорганізмів шлунково-кишкового тракту в організмі людини утворюються нітрозоаміни і нітрозоаміди, що спричиняють онкозахворювання, негативно впливають та руйнують нервову й серцевосудинну системи, перешкоджають нормальному розвитку ембріонів $[4,5,7,12]$. У головному нормативному документі якості води «Державні санітарні правила і норми. Вода питна. Гігієнічні вимоги до якості води централізованого господарсько-питного водопостачання» (ДСанПін) встановлена максимальна допустима концентрація нітрат-іонів, у перерахунку на нітратний азот, у воді питного призначення - 11 мг/дм ${ }^{3}$ [2].

У попередніх дослідженнях $[11,14]$ виявлено, що очищення води від нітрат-іонів на побутовому рівні $\epsilon$ неможливим, тому населення, закуповуючи дорогі фільтри, не може забезпечити себе якісною водою відносно нітратів. Ця проблема досліджена в роботах, де експерименти проводилися 3 використанням медичного активовано- 


\section{TEХНІЧНІ НАУКИ}

го вугілля, і було виявлено, що позитивного ефекту така очистка не дає, а, навпаки, після контакту iз сорбентом вода стала непридатною для вживання як питна за такими показниками як вміст водорозчинних солей, органічних сполук, лужності та рН. Тому проблема очищення води для питного користування від нітрат-іонів залишається надзвичайно актуальною. Ми виконали серію експериментів із пошуку сорбенту на нітрат-іони. Глиниста порода була вибрана в якості досліджуваного матеріалу (сорбенту), поскільки вода, проходячи через товщу земної кори, фільтрується від забруднюючих речовин.

Метою роботи було дослідити сорбційні властивості глинистої сировини відносно нітратіонів для одержання якісного сорбенту, здатного поліпшити якість питної води, а також виявити вплив його сорбційних властивостей на інші фізико-хімічні показники води. Основними вимогами для дослідженого матеріалу ми ставили хороші сорбційні властивості відносно нітратіону, його легкодоступність, достатню кількість, а, відповідно, низьку собівартість, адже від забруднення нітрат-іонами потерпає населення сільської місцевості, яке не спроможне закуповувати дорогі фільтри.

Завдання: знайти дешевий та одночасно доступний сорбент на нітрат-іони; дослідити його сорбційні властивості відносно дистильованої та природної питної води.

Матеріали і методи досліджень. Глиниста сировина - високодисперсна осадова гірська порода групи шаруватих або шарувато-стрічкових силікатів, що відрізняється гідрофільністю й здатністю до сорбції та іонного обміну [10]. У природних умовах глинисті мінерали мають розмір частинок не більше 1-10 мкм і тому зустрічаються в найбільш тонкій (глинистій) фракції осадових порід, до якої зазвичай відносять частинки розміром менше 1 мкм.

Глинисту сировину широко застосовують у промисловості, зокрема: у виробництві керамічних виробів, вогнетривів, тонкої кераміки, фарфоро-фаянсових та санітарно-технічних виробів; у будівельній промисловості (виробництві цегли, керамзитобетону, керамзитобетонних блоків, стінових панелей та ін.), як тепло- та звукоізоляційний матеріал й інших будівельних матеріалів; для побутових потреб, у косметології, а також як матеріал для декоративно-прикладного мистецтва та архітектури.

Використання глин для очищення побутових стічних вод має широке застосування [8, 9, 13]. Однак ми пропонуємо використовувати глинисту сировину 3 підвищеним вмістом оксиду кремнію $\left(\mathrm{SiO}_{2}\right)$ і меншим полуторних оксидів заліза та алюмінію $\left(\mathrm{Fe}_{2} \mathrm{O}_{3}+\mathrm{Al}_{2} \mathrm{O}_{3}\right)$ для очищення питної води від нітрат-іонів. У такий спосіб ми намагалися уникнути десорбції можливих домішок глинистої сировини у питну воду.

Хімічний склад глинистої сировини, визначений відповідно [1], наведений у таблиці 1.

Оскільки обмінні процеси в системі сорбентрозчин залежать від багатьох параметрів, одним i3 яких $\epsilon$ й первинний хімічний склад розчину (природної води), то важливим фактором є відсутність токсичних іонів, які попередньо могли знаходитися у природному сорбенті.

Перевагами використання запропонованого нами сорбенту - глинистої сировини із підвищеним вмістом $\mathrm{SiO}_{2}-\epsilon$ покращання основних показників якості води у відповідності до вимог, потужні поклади природного залягання, низька собівартість видобутку, мінімальні енергозатрати щодо підготовки до використання - тому й дешевизна та доступність для населення із низьким рівнем доходів, відсутність необхідності регенерації, можливість безвідходного використання у будівельній промисловості, тобто екологічна безпека використання. Проби глинистої сировини були попередньо доведені до повітряно-сухого стану (зразок 1).

\section{1. Склад глинистої сировини}

\begin{tabular}{|c|c|}
\hline Показник & Глиниста сировина \\
\hline $\mathrm{SiO}_{2}$ & $84,4 \%$ \\
\hline $\mathrm{Fe}_{2} \mathrm{O}_{3}+\mathrm{Al}_{2} \mathrm{O}_{3}$ & $5,83 \%$ \\
\hline $\mathrm{Fe}_{2} \mathrm{O}_{3}$ & $1,46 \%$ \\
\hline \multirow{2}{*}{ ВПП } & при $700{ }^{\circ} \mathrm{C}-9,75 \%$ \\
\hline & при $1000{ }^{\circ} \mathrm{C}-10,3 \%$ \\
\hline Вміст органічних речовин & $0,2 \%$ \\
\hline Гігроскопічна вологість & $4,83 \%$ \\
\hline Вміст кристалізаційної води & $4,72 \%$ \\
\hline
\end{tabular}




\section{TEХНІЧНІ НАУКИ}

Крім того ми виконали їх термічну обробку, а саме, попередньо прожарили до постійної маси частину проби за температури $700{ }^{\circ} \mathrm{C}$ (зразок 2) та температури $1000{ }^{\circ} \mathrm{C}$ (зразок 3 ). 3 усіма зразками ми провели комплекс досліджень із вивчення їх сорбційних властивостей.

Наважки глинистої сировини витримували у водному розчині нітрату калію із концентрацією нітрат-іонів у перерахунку на нітратний азот $10 \mathrm{мг} /$ дм $^{3}$. Через рівні проміжки часу визначали залишкову концентрацію нітрат-іонів у розчині.

Результати досліджень представлені на графіку. 3 графіка видно, що сорбція починається 3 перших секунд контакту в усіх трьох випадках, але у випадку першому (глина у повітряносухому стані) сорбція $є$ незначною.

3-поміж двох інших випадків кращу здатність до поглинання нітрат-іонів показав зразок №2, прожарений за температури $700{ }^{\circ} \mathrm{C}$ (лінія 2). За високих температур $\left(1000^{\circ} \mathrm{C}\right)$ змінюються структурно-текстурні характеристики досліджуваної сировини (зразок №3), що впливають на сорбційні властивості. Тому подальші експерименти проводилися із зразком №2.

Запропонований нами спосіб полягає у наступному: глинисту сировину піддавали попередньому прожарюванню за температури $700{ }^{\circ} \mathrm{C}$ протягом одної години, поскільки після такої обробки видаляються леткі сполуки, гігроскопічна та кристалізаційна вода, органічні речовини, однак не відбувається спікання й зберігається дрібнодисперсність.

В усіх експериментах використовували сорбент і досліджувану воду у співвідношенні 1:15, після чого пропускали через фільтр «Синя стрічка» та визначали в фільтраті вміст нітрат-іонів за методикою ГОСТ 18826-73 та інших показників відповідно до стандартних методик, описаних у [2].

Ми дослідили вплив запропонованого сорбенту на дистильовану воду й на природну питну воду. Результати подані у таблиці 2.

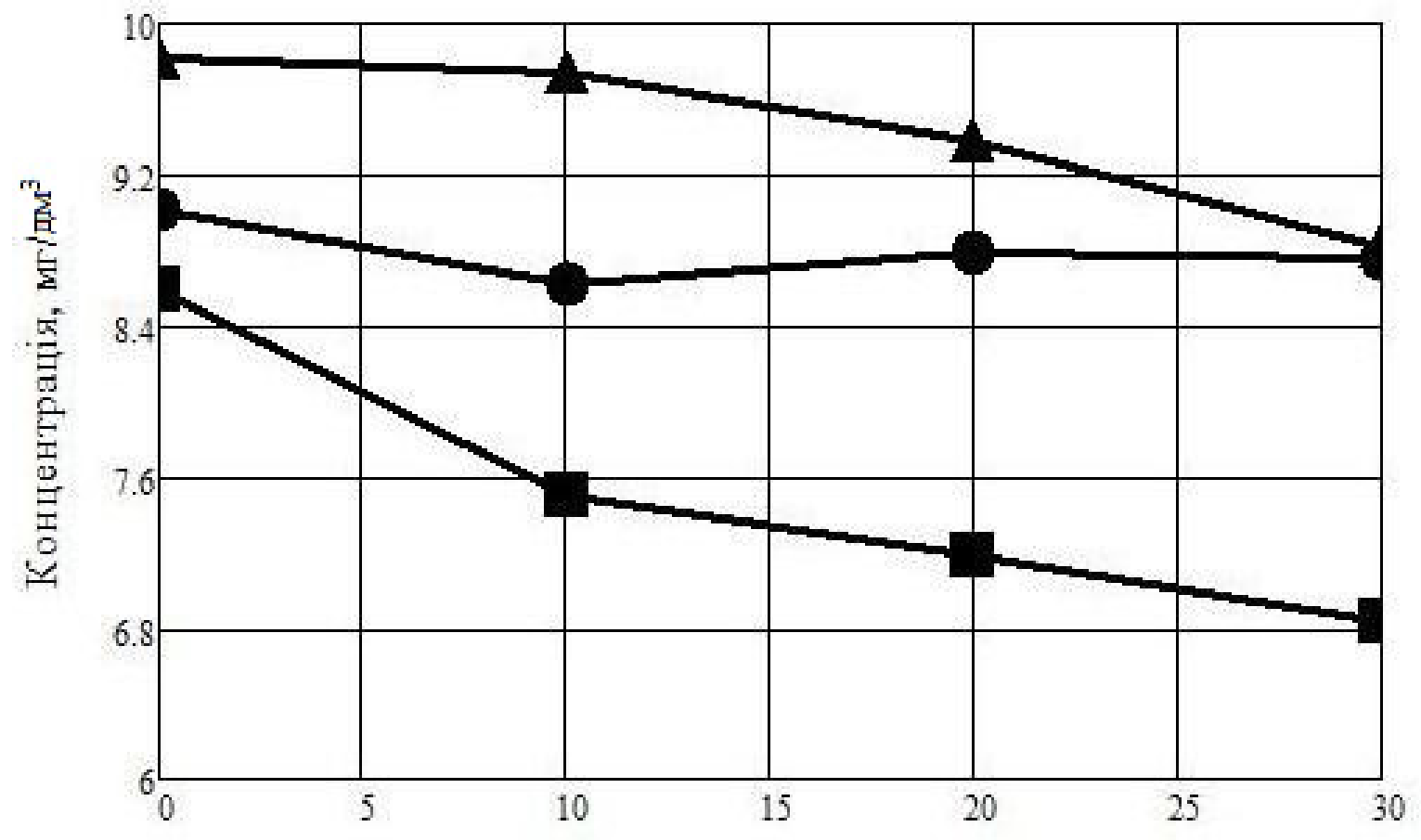

Чac, xB.

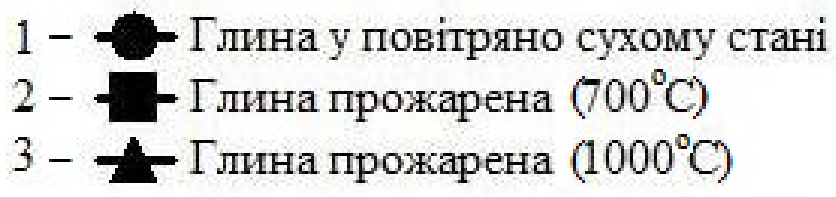

Графік. Залежність концентрації нітратного азоту від часу контакту із сорбентом у повітряно-сухому стані та прожареній за температур $700{ }^{\circ} \mathrm{C}$ i $1000^{\circ} \mathrm{C}$ 
TEХНIЧНI НАУКИ

\section{2. Показники якості дистильованої води після обробки, питної природної води до та після обробки сорбентом}

\begin{tabular}{|c|c|c|c|}
\hline Показник & $\begin{array}{c}\text { Вода дистильована } \\
\text { (після обробки) }\end{array}$ & $\begin{array}{l}\text { Вода природна } \\
\text { (до обробки) }\end{array}$ & $\begin{array}{l}\text { Вода природна } \\
\text { (після обробки) }\end{array}$ \\
\hline Інтенсивність запаху, бали & 0 & 0 & 0 \\
\hline Інтенсивність смаку, бали & 0 & 0 & 0 \\
\hline Колірність, град & 0 & 3 & 1 \\
\hline Жорсткість загальна, ммоль-екв/мд³ & 2,04 & 7,7 & 5,8 \\
\hline Жорсткість кальцієва, ммоль-екв/мд & 1,92 & 6,8 & 3,9 \\
\hline Жорсткість магнієва, ммоль-екв/мд ${ }^{3}$ & 0,12 & 0,9 & 1,9 \\
\hline Лужність, ммоль-екв/мд³ & - & 4,0 & 4,0 \\
\hline Нітрат-іони (нітратний азот), мг/дм³ & 0,0 & 25,4 & 11,8 \\
\hline Солевміст, мг/дм ${ }^{3}$ & 31,35 & 627 & 711 \\
\hline
\end{tabular}

Очевидним $є$ значне покращання якості природної питної води за показниками загальної жорсткості та вмістом нітрат-іонів.

Глиниста сировина не десорбує у природну воду ніяких макрокомпонентів.

Збільшення вмісту водорозчинних солей $є$ несуттєвим і не виходить за значення, дозволене ДСанПіНом.

Хоча у дистильовану воду відбувається десорбція незначної кількості іонів кальцію, у природній воді, навпаки, відбувається адсорбція, в той час як десорбція іонів магнію у природну воду є більш суттєвою (в межах норми), що значно покращує якість питної природної води.

Крім того спостерігається зменшення значення колірності.

\section{БІБЛІОГРАФІЯ}

1. ГОСТ 5382-91, ГОСТы 21216.0-93-21218.493; 21216.6-93-21216.12-93. Сырье глинистое. Методы анализа.

2. Державні санітарні норми та правила «Гігієнічні вимоги до води питної, призначеної для споживання людиною» (ДСанПіН 2.2.4-171-10).

3. Дорогуниов С. I. Природні ресурси: екологоекономічна оцінка / С. І. Дорогунцов, А. М. Муховиков, М. А. Хвесик. - К. : Кондор, 2004. - 291 с.

4. Екологічний атлас Полтавщини. Навчальне видання / За ред. Ю. С. Голіка, В. А. Барановського, О. Е. Ілляш. - Полтава : Полтавський літератор, 2007. - $128 \mathrm{c}$.

5. Коваленко O. М. Нітрат- нітритна проблема та шляхи iï вирішення / О. М. Коваленко, А. І. Горобець, А. М. Кучук // Науч. зап. Харьковского института экологии и социальной защиты. - Х., 2002 - T. 2. - C. 3-13.

6. Кульский Л. А., Левченко Т. М., Петрова М. В. Химия и микробиология воды / Л. А. Кульский, Т. М. Левченко, М. В. Петрова. - К. : Вища шко-
Висновки: 1. Глиниста сировина володіс адсорбційними властивостями відносно нітратіону з перших секунд контакту.

2. Сорбційні властивості глинистої сировини залежать від температури попереднього прожарювання та часу контакту з розчином.

3. Сорбційні властивості глини залежать від текстурно-структурних особливостей, що змінюються за високих температур.

4. Непрожарена глина має найменші адсорбційні властивості.

5. Виявлено, що найкращим сорбентом є глина, прожарена за температури $700{ }^{\circ} \mathrm{C}$.

6. Виявлено покращання якості природної питної води за вмістом нітрат-іонів, загальної та магнієвої жорсткості.

ла, 1976. - $116 \mathrm{c.}$

7. Лазарев М. В. Вредные вещества в промышлености / М. В. Лазарев // Справочник для химиков. В трех томах. - Т. III. - Л. : Химия, 1977. $608 \mathrm{c}$.

8. Опис до патенту на винахід UA $83955 \mathrm{C} 2$ МПК (2006) CO2F 1/28 BО1J 20/16 (2008.1).

9. Применение сорбента вермикулитового [Електронний ресурc]. - Режим доступу http:// rosbp.com/products/vermisorb/?action=pubs\&id $=11$.

10. Сергеев Е. М. Грунтоведение / Е. М. Сергеев, В. А. Голодовская. - М. : Изд-во Московского университета, 1985. - С. 37.

11. Стороженко Д. О., Сененко Н. Б., Шимченко А. Ю., БутенкоГ. І., Оспішева А. С. Вивчення адсорбційних властивостей активованого вугілля та їх впливу на стан природної води. Дисперсные системы. - XXXIII научная конференция стран СНГ, 22-26 сент. 2008 г., Одесса, Украина : Материалы конференции / Министерство образования и науки Украины, Одесский 
нац. ун-т имени И. И. Мечникова. - Одесса: Астропринт, 2008. - 400 с.

12. Хмельнищкий Г. А. Ветеринарная токсикология / Г. А. Хмельницкий, В. Н. Локтинов, Д. Д. Полоз. М.: Агропромиздат, 1987. - 318 c.

13. Хоменко Віллен. Ефективні засоби очищення навколишнього середовища від шкідливого забруднення, в тому числі радіоактивного, 3 використанням природних сорбентів родовищ України [Електронний ресурс]. - Режим доступу http://korekta.io.ua/s202423/villen homenko. efekti vni_zasobi_ochishchennya_navkolishnogo_seredovi shcha_vid_shkidlivogo_zabrudnennya_v_tomu_chis li_radioaktivnogo_z_vikoristannyam_prirodnih_sor bentiv_rodovishch_ukraeni

14. Шимченко А. Ю., Стороженко Д. О., Сененко Н. Б. Вивчення впливу адсорбційних властивостей активованого вугілля на хімічний склад природної води. Актуальні питання теоретичної та прикладної біофізики, фізики та хімії «БФФХ2008» : Матеріали IV Всеукраїн. наук.-техн. конф., м. Севастополь, 21-26 квітня 2008 р. Севастополь: Вид-во СевНТУ, 2008. - 292 арк.

15. Яиик А. В. Водне господарство в Україні / А. В. Яцик. - К. : Генеза, 2000. -456 с. 